\title{
Assessment of Site Parameters and Heat Recovery Characteristics on Combined Cycle Performance in an Equatorial Environment
}

\author{
Sidum Adumene, Samson Nitonye \\ Department of Marine Engineering, Rivers State University of Science and Technology, Port Harcourt, Nigeria \\ Email: sidum.adumene@ust.edu.ng
}

Received 26 April 2016; accepted 24 May 2016; published 27 May 2016

Copyright (C) 2016 by authors and Scientific Research Publishing Inc.

This work is licensed under the Creative Commons Attribution International License (CC BY). http://creativecommons.org/licenses/by/4.0/

c) (i) Open Access

\section{Abstract}

This paper investigates the effects of site based parameters such as ambient temperature, humidity, altitude and heat transfer characteristic of a dual pressure heat recovery system on the performance of the combined cycle power plant within an equatorial environment. The bulk heat utilization and configuration of a dual pressure heat recovery system are investigated. It is observed that the heat system configuration play a vital role in optimizing the combined cycle overall performance, which has proportionality relationship with the operating ambient temperature and relative humidity of the gas turbine. The investigation is carried out within the ambient temperature range of $24^{\circ} \mathrm{C}$ to $35^{\circ} \mathrm{C}$, relative humidity of $60 \%$ to $80 \%$, and a high level steam pressure of 60 bar to 110 bar. The results show that at $24^{\circ} \mathrm{C}$ ambient temperature, the heat recovery system has the highest duty of 239.4 MW, the optimum combined cycle power output of $205.52 \mathrm{MW}$, and overall efficiency of $47.46 \%$. It further indicates that as the ambient temperature increases at an average exhaust gas temperature of $530^{\circ} \mathrm{C}$ and mass flow of $470 \mathrm{~kg} / \mathrm{s}$, the combined cycle power output and efficiency decrease by $15.5 \%$ and $13.7 \%$ respectively under the various considerations. This results from a drop in the air and exhaust mass flow as the values of the site parameters increase. The overall results indicate that decreasing the ambient temperature at optimum exhaust gas flow and temperature increases the heat recovery system heat duty performance, the steam generation, overall combined cycle power output and efficiency, which satisfies the research objective.

\section{Keywords}

Gas-Turbine, Ambient Temperature, Humidity, Combined Cycle, Efficiency, Power Output, HRSG 


\section{Introduction}

The growing need of energy in modern civilization has prompted the need to optimize energy sources globally. This can be enhanced through an effective parametric evaluation of exiting plant to minimize losses, and to understand the performance rate of such system. Although gas turbine is a very satisfactory means of producing mechanical power [1] [2], the combination of gas and steam turbines are the greatest means to generate mechanical power both for combined power generation and combined heat and power generation. Both gas and steam turbines have been successfully working in large scale to generate the electricity and steam for heating, whereas gas turbine ensures superior thermal efficiency as compared to steam turbine. The overall performance of the combined cycle power basically depends on the operating conditions of the gas turbine and the heat recovery steam generator (HRSG) configurations. According to [3], a reduction in the ambient temperature of a gas turbine plants within the tropical environment from $31^{\circ} \mathrm{C}$ to $18^{\circ} \mathrm{C}$ improves the power output by about $0.78 \%$. Many researchers focus on improving the modeling of combined cycle gas turbine (CCGT) power plant system to achieve efficient, reliable and economic power generation. Currently, commercially available generation CCGT power plants achieve total thermal efficiencies typically in the range $50 \%-60 \%$ based on the operating environment.

Heat recovery steam generator (HRSG) is the standard term used for a steam generator producing steam by cooling hot gases. Heat recovery system is obviously a very desirable energy source, since the product is available almost operating cost-free and increase the efficiency of the cycle in which it is placed, either for steam generation or for incremental power generation. So its performance and configuration have a great impact on the overall plant performance. We have two typical HRSG types, which are unfired and supplementary-fired. For the unfired HRSGs, we have less recovery efficiency and steam temperatures than supplementary-fired configurated HRSG [4]. In supplementary-fired HRSG, additional fuel can be sprayed into the exhaust stream to further increase efficiency and increase steam temperature to $850^{\circ} \mathrm{C}-900^{\circ} \mathrm{C}$ [5]. HRSG can have multiple stages of steam pressures and temperatures; typical configurations include single, dual and triple-pressure levels [6]. These pressure levels are termed low pressure (LP), intermediate pressure (IP) and high pressure (HP), in which case, each pressure level comprises of three heat exchangers or heating elements of economizer, evaporator, and superheater.

In the work of [7] on a novel heat-recovery process for improving the thermal efficiency of a gas turbine in electric power generation, it explains that the resultant mass flow from the evaporation of heated water into the combustion air reduces the power required to compress the air and permits better utilization of the otherwise wasted heat. Calculation of the efficiency of the system indicates $54.8 \%$, which is better compared to an inter-cooled, steam-injected system. Reference [8] carries out a performance optimization of dual pressure HRSG in the tropical rainforest. Their work shows that increasing the exhaust gas temperature from $490^{\circ} \mathrm{C}$ to $526^{\circ} \mathrm{C}$ and mass flow by $80 \mathrm{~kg} / \mathrm{s}$, the overall heat absorbed by the HRSG increases by $37.39 \%$, while the steam generates increase by $19.29 \%$ and $18.18 \%$ for the low pressure (LP) and high pressure (HP) levels respectively. This shows an increase in the overall plant performance.

In the work [9], they did a parametric analysis for a plant equipped with a gas generator and with steam injection into an after-burner placed upstream of the power turbine through a waste-heat recovery steam production and distillation plants fed by the gas turbine exhaust. A 13\% improvement in plant efficiency and a doubling of the specific work output when compared with a standard gas turbine cycle with full reheat and optimal steam injection was the result. Reference [10] carried out a study on a combined cycle with advanced options namely Compressor air intercooling, water injection and reheating, including environmental and economic analysis. Their work provides a validity of methods for the development of energy system performance framework. The work of [11] revealed that a heat flow of about $42.46 \mathrm{MW}$ which was otherwise being wasted in the exhaust gas of the plant was converted to $12.9 \mathrm{MW}$ of electric power through steam topping plant incorporation, with a single pressure heat recovery steam generator.

In the work of [12], the effect of operating parameters on combined cycle performance was analyse to achieved an efficient, reliable and economic power generation. They further stated that the major operating parameters which influence the combined cycle are; turbine inlet temperature, compressor pressure ratio, pinch point, ambient temperature and pressure levels. Again, [13] did performance simulation of HRSG in combined cycle power plant, discussing the effect of various parameters like pinch point, approach point, steam pressure, steam temperature, gas flow rate on the performance of the HRSG. Also [14] noted that the mass flow rate of steam and steam temperature in a combined cycle system depends on the amount of heat available in the gas turbine 
exhaust. And [15] observed that with increased turbine inlet temperature (TIT), the performance of HRSG and consecutively the steam turbine improves thereby, offering improvement in combined cycle performance while [16] examined the improvements in efficiency with increases in boiler pressure, turbine inlet temperature and furnace temperature.

Reference [17] did a parametric thermodynamic analysis of a combined cycle investigating the effect of operating parameters on the overall plant performance. The simulation results showed that the overall efficiency increases with the increase of the peak compression ratio. The peak overall efficiency occurs at higher compression ratio with low ambient temperature and higher turbine inlet temperature. The overall thermal efficiencies for CCGT are higher compared to that of the gas-turbine plants. The work of [18] analysed a small-scale aeroderivative industrial gas turbine using combined heat-and-power (CHP) application. Their work shows that the recuperated cycle (RC) produces the highest HRSG duty as compared to intercooled-recuperated (ICR) and simple cycle (SC). The HRSG duty was found to be $3171.3 \mathrm{~kW}$ for recuperated cycle (RC) which reflects on the overall plant efficiency.

The objective of this investigation is to evaluate the effects of site based parameters and heat system characteristic on the overall combined cycle power plant efficiency and power output within the equatorial environment. The parameters used in the analysis include the ambient temperature, humidity, heat duty, log mean temperature difference (LMTD), heat transfer coefficient per unit area, steam pressure, exhaust gas temperature, and mass flow. The study area is the South-South zone of Nigeria which lies between latitudes $4^{\circ} \mathrm{N}$ and $6^{\circ} \mathrm{N}$, and longitude $5^{\circ} \mathrm{E}$ and $8^{\circ} \mathrm{E}$. The vegetation of the area is equatorial rain forest. There are basically two seasons - the wet (April to September) and the dry (October to March). However, rain fall throughout the year. The mean annual rainfall in the area is between $200 \mathrm{~mm}$ in the North and $400 \mathrm{~mm}$ in the South of the region. The mean daily temperature of the region varies slightly from $27^{\circ} \mathrm{C}$ to $30^{\circ} \mathrm{C}$ all the year round. The maximum and minimum temperatures are $40^{\circ} \mathrm{C}$ and $20^{\circ} \mathrm{C}$ respectively. The relative humidity varies between a minimum of $50 \%$ and a maximum of $90 \%$ [19] [20].

\section{Materials and Methods}

The research methods adopted involved the collection of data from the plant station for 12 months as follows:

1) Direct monitoring and measurement from the control room through the human machine interface (HMI)

2) Direct reading of design parameter from engine manual.

3) Field study of the overall plant in wet and dry season.

4) Modeling energy based (thermodynamic) relations and equation for parameters that could not be directly measured.

5) Results from the modeling equations were analysis, discussed and conclusion were made.

The methodology adopted was designed to produce facts about the behavior of the plant, and to determine those factors that influence the combined cycle thermodynamic process within the equatorial environment. Hysys ${ }^{\circledR}$ V8.7 software (Aspentech, USA) was used to process the temperature gradient across the various heat exchanging units of the HRSG at various ambient temperatures of the gas turbine. MATLAB $7.3^{\circledR}$ (Mathworks USA) was used to evaluate the equations. Thermodynamics properties such as temperature, pressure, mass flow, heat flow, compression ratio and turbine inlet temperatures (TIT) are crucial in this research because their behavior affect every other parameter in the analysis.

In the data collection and treatment, the mean values of daily parameters were considered by the use of statistical method.

\section{Modeling Relations and Equations}

The net power output $\left(W_{\text {net }}\right)$ is the power generated by the generator and is given as

$$
W_{\text {net }}=W_{T}-W_{C}
$$

where $W_{T}$ is the shaft work of the turbine and is given as

$$
W_{T}=m_{g} c_{p g}\left(T_{4}-T_{3}\right)
$$

and $W_{C}$ is the compressor work given as

$$
W_{C}=m_{a} c_{p a}\left(T_{2}-T_{1}\right)=\rho_{a} V_{a} c_{p a}\left(T_{2}-T_{1}\right)
$$


where $m_{g}$ is the mass of the product of combustion $(\mathrm{kg} / \mathrm{s}), c_{p g}$ is the specific heat capacity of the product of combustion, $T_{3}$ is the TIT, $m_{a}$ is the mass of air $(\mathrm{kg} / \mathrm{s}), c_{p a}$ is the specific heat capacity of air, $\rho_{a}$ is density of air, $V_{a}$ is volume of air aspirated by the compressor, $T_{1}$ is the ambient temperature.

The humidity relation gives

$$
\omega=\frac{0.622 \varnothing P_{a}}{P-P_{v}}
$$

where $\phi$ is the relative humidity $\left(P_{v} / P_{a}\right)$ and the mass flow $M=m_{a}=\left(1+0.622 \varnothing \frac{P_{s}}{P_{a}}\right)$.

The overall heat transfer coefficient $U$ can be determined by the equation

$$
U=\frac{Q}{(f \cdot L M T D) \times A_{T}}
$$

where $A_{T}=A_{\text {hrsg }}=\sum_{S H} A_{S H}+\sum_{E V} A_{E V}+\sum_{E C O} A_{E C O}$

$f=$ Correction factor obtained from charts.

The Log Mean Temperature Difference (LMTD)

$$
L M T D=\left[\frac{\left(T_{g i}-T_{w e}\right)-\left(T_{g e}-T_{w i}\right)}{\ln \left(\frac{T_{g i}-T_{w e}}{T_{g e}-T_{w i}}\right)}\right]
$$

where $T_{g i}$ is the exhaust gas temperature into the HRSG elements $\left({ }^{\circ} \mathrm{C}\right)$.

$T_{g e}=$ Exhaust gas temperature out of the HRSG elements $\left({ }^{\circ} \mathrm{C}\right)$.

$T_{w i}=$ Temperature of feed water/steam into the HRSG elements $\left({ }^{\circ} \mathrm{C}\right)$.

$T_{w e}=$ Temperature of feed water/steam out of the HRSG elements $\left({ }^{\circ} \mathrm{C}\right)$.

The Heat Duty of the HRSG heating surfaces are evaluated using the equations

$$
Q_{K}=m_{s}\left(h_{s s}-h_{s}\right)_{R}=m_{g} C_{p g}\left(T_{\text {in }}-T_{\text {out }}\right)
$$

where $K$ signifies $H P_{S H}, H P_{E V}, H P_{E C O}$ respectively

$$
Q_{X}=m_{s}\left(h_{s s}-h_{s}\right)_{R}=m_{g} C_{p g}\left(T_{\text {in }}-T_{\text {out }}\right)
$$

where $X$ signifies $L P_{S H}, L P_{E V}, L P_{E C O}$ respectively and $R$ signify $H P$ and $L P$ respectively.

The steam generation can be evaluated using the equations

$$
m_{R}=\frac{m_{g} C_{p g}\left(T_{g 1}-T_{g 4}\right)}{\left(h_{s s}-h_{s}\right)_{R}}
$$

The steam turbine work can be evaluated using the equation

$$
W_{S T}=m_{s}\left(h_{s s}-h_{c}\right)
$$

The condensate from the condenser is extracted by the pump and is raised to the economizer pressure. The corresponding work is given by

$$
w_{p}=m_{w} \times v_{f} \times\left(P_{s h}-P_{c}\right)
$$

Therefore the net power output for the steam turbine is given by

$$
W_{\text {SNet }}=W_{S T}-W_{P}
$$

The efficiency for the steam turbine is evaluated using the equation

$$
\eta_{S T}=\frac{W_{\text {SNet }}}{Q_{\text {HRSG }}}
$$


The overall thermal efficiency for the combined power plant is

$$
\eta_{\text {all }}=\frac{W_{G N e t}+W_{S N e t}}{Q_{\text {add }}}=\eta_{G T}+\eta_{S T}-\eta_{G T} \eta_{S T}
$$

\section{Results and Discussion}

The parameters in Table 1 were obtained from the installation manual of GT13E2 Gas Turbine, HRSG and Steam Turbine plant. The turbine measured operational parameters is indicated in Table 2 . The effect of the gas turbine ambient conditions on the HRSG heat transfer performance is presented in Table 3, while the steam

Table 1. Design data.

\begin{tabular}{cccc}
\hline S/NO & Parameter & Units & Design Data \\
\hline 1 & Gas Turbine Power Output & $\mathrm{MW}$ & 160 \\
2 & Thermal Efficiency & $\%$ & 35.7 \\
3 & Heat Rate (HR) & $\mathrm{kJ} / \mathrm{kWh}$ & 10,084 \\
4 & Compressor Ratio & & $14: 1$ \\
5 & HRSG MCR (LP) & $\mathrm{kg} / \mathrm{s}$ & 80 \\
6 & HRSG MCR (HP) & $\mathrm{kg} / \mathrm{s}$ & 220 \\
7 & Steam Turbine Power Output & $\mathrm{MW}$ & 100 \\
9 & Isentropic Efficiency & $\%$ & 89.06 \\
10 & Thermal Efficiency & $\%$ & 30.25 \\
\hline
\end{tabular}

Table 2. Ambient temperature and turbine inlet temperature and power output.

\begin{tabular}{ccccccc}
\hline $\begin{array}{c}\text { Ambient } \\
\text { Temp. }{ }^{\circ} \mathrm{C}\end{array}$ & $\begin{array}{c}\text { Compressor Exit } \\
\text { Temp. }{ }^{\circ} \mathrm{C}\end{array}$ & $\begin{array}{c}\text { Exhaust } \\
\text { Temp }{ }^{\circ} \mathrm{C}\end{array}$ & $\begin{array}{c}\text { Actual Power } \\
\text { Output MW }\end{array}$ & $\begin{array}{c}\text { Thermal } \\
\text { Efficiency \% }\end{array}$ & $\begin{array}{c}\text { Power } \\
\text { Drop (\%) }\end{array}$ & $\begin{array}{c}\text { Thermal Efficiency } \\
\text { Drop (\%) }\end{array}$ \\
\hline 24 & 319.2 & 547.62 & 148.4 & 30.55 & 7.25 & 14.43 \\
25 & 332.5 & 554.62 & 148.0 & 29.78 & 7.50 & 16.58 \\
26 & 345.8 & 561.62 & 147.2 & 29.01 & 8.00 & 18.74 \\
27 & 359.1 & 568.62 & 145.1 & 28.24 & 9.31 & 20.89 \\
28 & 372.4 & 575.62 & 143.2 & 27.51 & 10.50 & 22.94 \\
29 & 385.7 & 582.62 & 140.3 & 26.70 & 12.31 & 25.21 \\
30 & 399 & 589.62 & 133.1 & 25.93 & 16.81 & 27.37 \\
33 & 412.3 & 596.62 & 132.3 & 25.16 & 17.31 & 29.52 \\
\hline 35 & 425.6 & 603.62 & 131.5 & 24.39 & 17.81 & 31.68 \\
\hline
\end{tabular}

Table 3. Impact of site parameters on heat characteristic performance of the system.

\begin{tabular}{|c|c|c|c|c|c|c|c|c|}
\hline \multirow[t]{2}{*}{$\begin{array}{l}\text { HRSG } \\
\text { Elements }\end{array}$} & \multicolumn{2}{|c|}{$\begin{array}{l}\text { Amb. Temp } 24^{\circ} \mathrm{C} \text {, Humidity } \\
60 \% \text {, Exhaust Temp } 545^{\circ} \mathrm{C}\end{array}$} & \multicolumn{2}{|c|}{$\begin{array}{l}\text { Amb. Temp } 30^{\circ} \mathrm{C} \text {, Humidity } \\
65 \% \text {, Exhaust Temp } 535^{\circ} \mathrm{C}\end{array}$} & \multicolumn{2}{|c|}{$\begin{array}{l}\text { Amb. Temp } 33^{\circ} \mathrm{C} \text {, Humidity } \\
70 \% \text {, Exhaust Temp } 500^{\circ} \mathrm{C}\end{array}$} & \multicolumn{2}{|c|}{$\begin{array}{l}\text { Amb. Temp } 35^{\circ} \mathrm{C} \text {, Humidity } \\
80 \% \text {, Exhaust Temp } 480^{\circ} \mathrm{C}\end{array}$} \\
\hline & Heat Duty (kW) & LMTD & Heat Duty $(\mathrm{kW})$ & LMTD & Heat Duty (kW) & LMTD & Heat Duty (kW) & LMTD \\
\hline HPSH & 30,839 & 82.49 & 29,157 & 106.60 & 16,821 & 90.98 & 17,382 & 60.35 \\
\hline HPEVA & 57,192 & 112.48 & 64,014 & 118.53 & 75,135 & 108.43 & 49,903 & 75.1 \\
\hline HPECO & 57,753 & 112.48 & 43,735 & 62.07 & 40,372 & 72.63 & 34,764 & 69.92 \\
\hline LPSH & 25,232 & 87.81 & 22,428 & 60.41 & 15,700 & 67.98 & 33,082 & 64.28 \\
\hline LPEVA & 41,493 & 51.35 & 52,146 & 21.05 & 27,186 & 73.98 & 30,839 & 63.87 \\
\hline LPECO & 26,914 & 33.84 & 19,064 & 18.57 & 24,857 & 38.50 & 31,400 & 60.65 \\
\hline
\end{tabular}


pressure effects on steam generation is presented in Table 4. The effects of ambient temperatures, humidity, steam pressure, and HRSG heat duty characteristic on the combined cycle overall performance in term of power output and efficiency is presented in Table 5.

Figures 1-3 present the effects of the ambient conditions on the turbine system key parameters such as the compressor exit temperature, turbine inlet temperature, power out and thermal efficiency of the plant. Figure 2 specifically show that there is a fall in the power output of about $2.16 \%$ for every $1^{\circ} \mathrm{C}$ rise in the ambient temperature. This means that if a gas turbine operated at an average temperature of $30^{\circ} \mathrm{C}$ instead of $15^{\circ} \mathrm{C}$ used at design stage, there will be a fall in power output of $27.7 \mathrm{MW}$ for a gas turbine design to generate $160 \mathrm{MW}$ at $15^{\circ} \mathrm{C}$ ISO condition. Also there is a rise in the percentage power drop of $1.32 \%$ for every $1^{\circ} \mathrm{C}$ rise in the ambient temperature. This indicates that the \% power drop increase wise increase in the ambient temperature. This accounted for one of the reason for power output losses within the tropical rainforest. The thermal efficiency of the turbine show similar trend, in that for every $1^{\circ} \mathrm{C}$ rise in the ambient temperature, the \% thermal efficiency drop is $2.16 \%$ as indicated in Figure 3.

Figure 4 show that for every $1^{\circ} \mathrm{C}$ rise in ambient temperature at a simultaneous decrease in the exhaust gas flow and temperature, the HRSG heat duty drop by $6.66 \%$, while the heat transfer coefficient per unit area decrease by $12.25 \%$. This means that the heat transfer performance of the HRSG increases with decrease in the ambient temperature, when the gas turbine has better performance. At $24^{\circ} \mathrm{C}$ ambient temperature, the LMTD performance evaluation of the HRSG gave an optimum value, showing better heat transfer performance of the HRSG. It further revealed that for at $24^{\circ} \mathrm{C}$ ambient temperature, any increase in the steam pressure by 1 bar increases the steam generation by about $0.69 \%$ and $0.77 \%$ for the HP and LP levels respectively. At $30^{\circ} \mathrm{C}$ ambient

Table 4. Impact of site parameters on steam generation performance of the system.

\begin{tabular}{|c|c|c|c|c|c|c|c|c|c|}
\hline \multicolumn{2}{|c|}{$\begin{array}{l}\text { Steam Pressure } \\
\text { (Bar) }\end{array}$} & \multirow{2}{*}{\multicolumn{2}{|c|}{$\begin{array}{c}\text { Amb. Temp } 24^{\circ} \mathrm{C} \text {, } \\
\text { Humidity } 60 \% \text {, Exhaust } \\
\text { Temp } 545^{\circ} \mathrm{C} \\
\begin{array}{c}\text { Steam Generation } \\
(\mathrm{kg} / \mathrm{s})\end{array}\end{array}$}} & \multirow{2}{*}{\multicolumn{2}{|c|}{$\begin{array}{c}\text { Amb. Temp } 30^{\circ} \mathrm{C} \text {, } \\
\text { Humidity } 65 \% \text {, Exhaust } \\
\text { Temp } 535^{\circ} \mathrm{C} \\
\begin{array}{c}\text { Steam Generation } \\
(\mathrm{kg} / \mathrm{s})\end{array}\end{array}$}} & \multirow{2}{*}{\multicolumn{2}{|c|}{$\begin{array}{c}\text { Amb. Temp } 33^{\circ} \mathrm{C} \text {, } \\
\text { Humidity } 70 \% \text {, Exhaust } \\
\text { Temp } 500^{\circ} \mathrm{C} \\
\text { Steam Generation } \\
(\mathrm{kg} / \mathrm{s})\end{array}$}} & \multirow{2}{*}{\multicolumn{2}{|c|}{$\begin{array}{c}\text { Amb. Temp. } 35^{\circ} \mathrm{C} \text {, } \\
\text { Humidity } 80 \% \text {, Exhaust } \\
\text { Temp } 480^{\circ} \mathrm{C} \\
\begin{array}{c}\text { Steam Generation } \\
(\mathrm{kg} / \mathrm{s})\end{array}\end{array}$}} \\
\hline \multirow[b]{2}{*}{ LP } & \multirow[b]{2}{*}{ HP } & & & & & & & & \\
\hline & & LP & HP & LP & HP & LP & HP & LP & HP \\
\hline 4 & 60 & 63.15 & 163.35 & 58.09 & 160.71 & 53.89 & 159.84 & 45.02 & 1499.82 \\
\hline 6 & 70 & 64.33 & 175.82 & 58.79 & 163.76 & 54.11 & 160.71 & 46.11 & 150.87 \\
\hline 8 & 80 & 65.51 & 180.52 & 59.70 & 166.68 & 54.33 & 162.87 & 47.98 & 153.72 \\
\hline 10 & 90 & 67.77 & 186.14 & 60.11 & 169.92 & 54.98 & 167.33 & 48.00 & 155.14 \\
\hline 12 & 100 & 69.93 & 194.02 & 61.34 & 173.38 & 55.82 & 168.14 & 48.83 & 159.17 \\
\hline 14 & 110 & 70.85 & 198.06 & 63.57 & 177.04 & 56.08 & 169.33 & 49.90 & 162.92 \\
\hline
\end{tabular}

Table 5. Performance impact of site parameters and heat recovery on combined cycle system.

\begin{tabular}{|c|c|c|c|c|c|c|c|c|c|}
\hline \multirow[t]{2}{*}{$\begin{array}{l}\text { Steam } \\
\text { Pressure } \\
\text { (Bar) }\end{array}$} & \multicolumn{3}{|c|}{$\begin{array}{l}\text { Amb. Temp } 24^{\circ} \mathrm{C} \text {, Humidity } 60 \% \text {, } \\
\text { Exhaust Temp } 545^{\circ} \mathrm{C}\end{array}$} & \multicolumn{3}{|c|}{$\begin{array}{l}\text { Amb. Temp } 30^{\circ} \mathrm{C} \text {, Humidity } 65 \% \text {, } \\
\text { Exhaust Temp } 535^{\circ} \mathrm{C}\end{array}$} & \multicolumn{3}{|c|}{$\begin{array}{l}\text { Amb. Temp } 35^{\circ} \mathrm{C} \text {, Humidity } 80 \% \text {, } \\
\text { Exhaust Temp } 480^{\circ} \mathrm{C}\end{array}$} \\
\hline & $\begin{array}{c}\text { CC } \\
\text { Power } \\
\text { Output } \\
\text { (MW) }\end{array}$ & $\begin{array}{c}\text { Total } \\
\text { Heat rate } \\
(\mathrm{kJ} / \mathrm{kWh})\end{array}$ & $\begin{array}{c}\text { CC Overall } \\
\text { Efficiency } \\
\text { (\%) }\end{array}$ & $\begin{array}{c}\text { CC } \\
\text { Power } \\
\text { Output } \\
\text { (MW) }\end{array}$ & $\begin{array}{c}\text { Total } \\
\text { Heat rate } \\
(\mathrm{kJ} / \mathrm{kWh})\end{array}$ & $\begin{array}{c}\text { CC Overall } \\
\text { Efficiency } \\
\text { (\%) }\end{array}$ & $\begin{array}{l}\text { CC } \\
\text { Power } \\
\text { Output } \\
\text { (MW) }\end{array}$ & $\begin{array}{c}\text { Total } \\
\text { Heat rate } \\
(\mathrm{kJ} / \mathrm{kWh})\end{array}$ & $\begin{array}{c}\text { CC Overall } \\
\text { Efficiency } \\
(\%)\end{array}$ \\
\hline 60 & 200.734 & 8.47 & 46.58 & 183.984 & 9.39 & 44.65 & 173.494 & 9.46 & 40.91 \\
\hline 70 & 204.443 & 8.34 & 47.15 & 184.603 & 9.45 & 44.84 & 173.388 & 9.65 & 40.86 \\
\hline 80 & 205.526 & 8.39 & 47.46 & 185.106 & 9.55 & 44.99 & 173.846 & 9.77 & 41.04 \\
\hline 100 & 206.959 & 8.39 & 47.88 & 185.749 & 9.62 & 45.2 & 174.869 & 9.92 & 41.06 \\
\hline 110 & 209.061 & 8.38 & 48.48 & 186.411 & 9.71 & 45.4 & 174.641 & 10.20 & 41.35 \\
\hline 120 & 206.401 & 8.42 & 47.71 & 185.130 & 9.79 & 44.39 & 172.591 & 10.10 & 40.55 \\
\hline
\end{tabular}




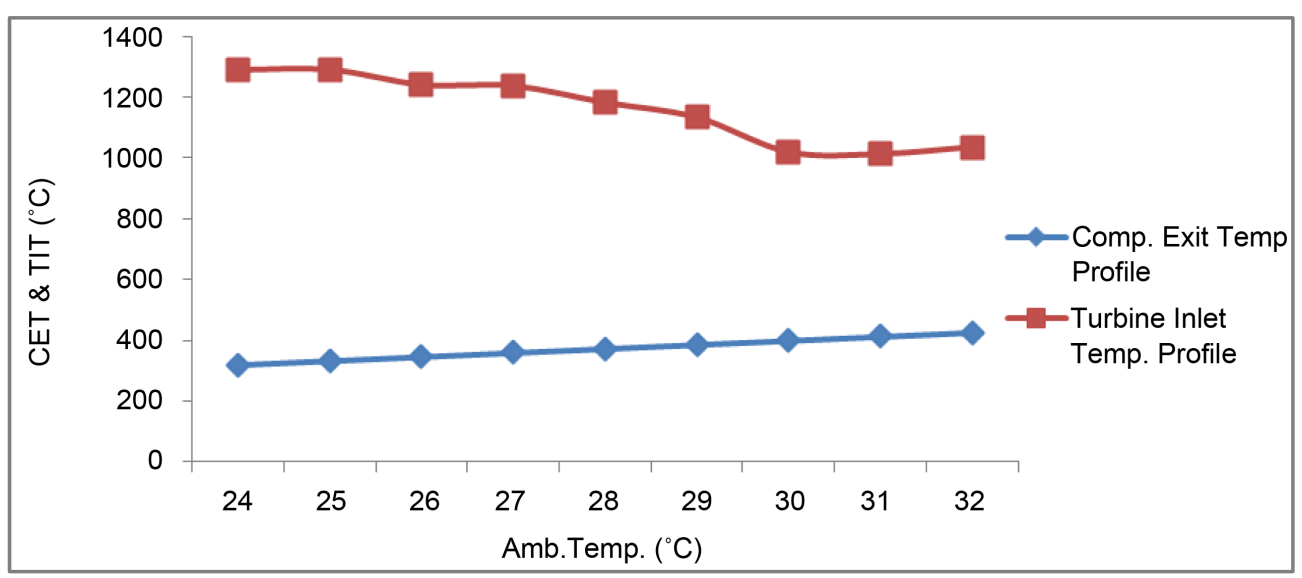

Figure 1. Effects of ambient temperature, humidity on compressor exit temperature and turbine inlet temperature.

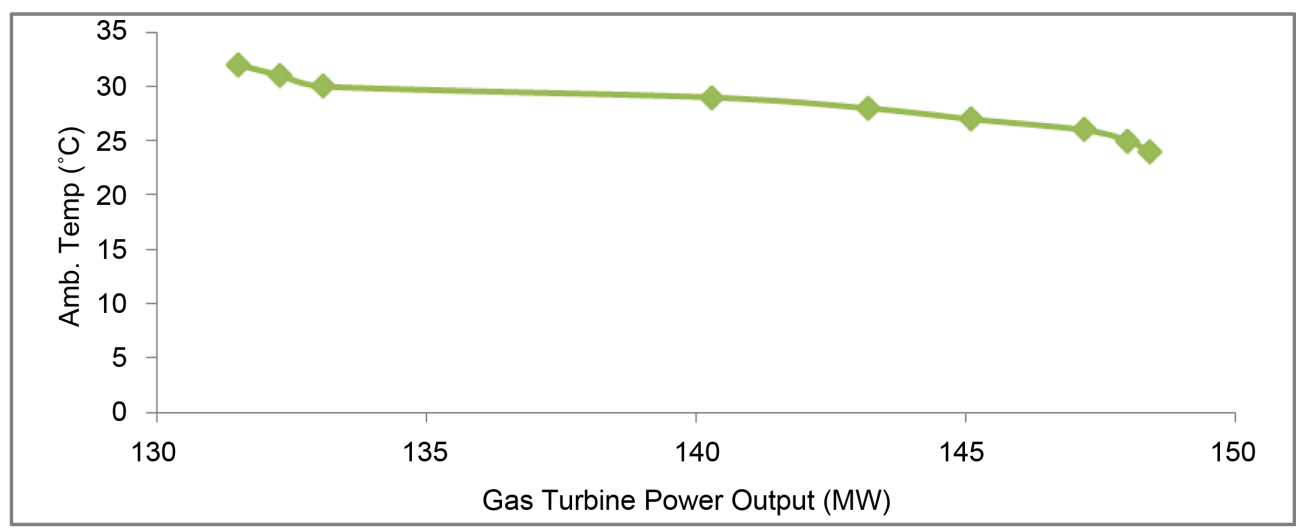

Figure 2. Effects of ambient temperature, humidity on gas turbine power output [21].

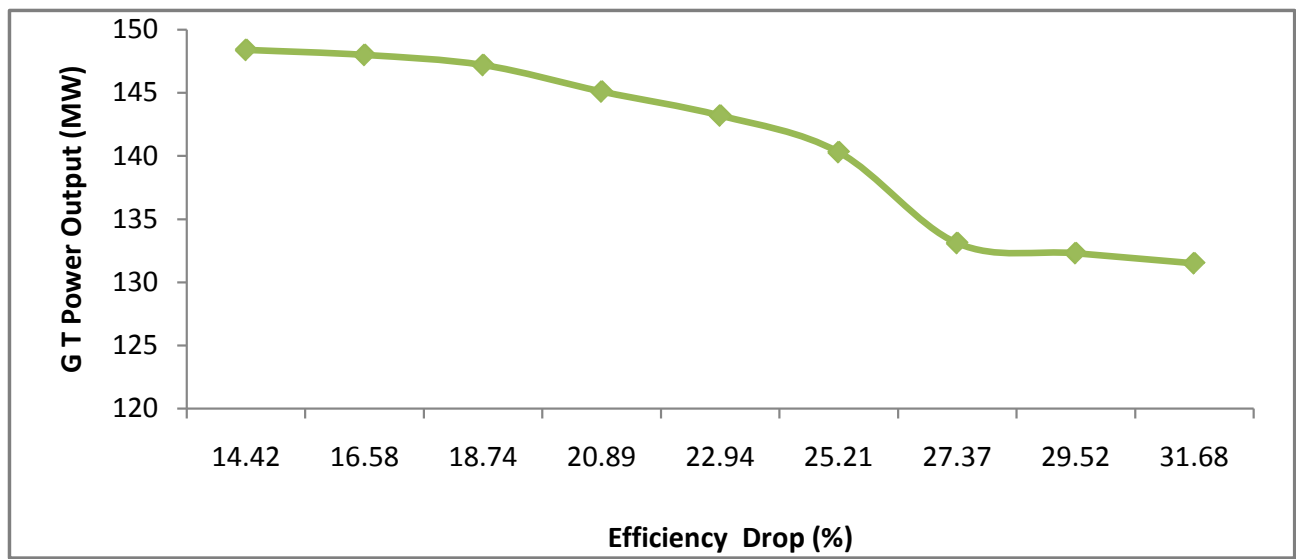

Figure 3. Effect of Percentage (\%) efficiency drop on gas turbine power output.

temperature, the steam generation increases by $0.33 \%$ and $0.55 \%$ for the HP and LP levels for every 1 bar rise in the steam pressure. At $33^{\circ} \mathrm{C}$ and $35^{\circ} \mathrm{C}$ ambient temperatures, the steam generation increase by $0.19 \%, 0.22 \%$ and $0.26 \%, 0.49 \%$ for the HP and LP respectively, for every 1 bar increase in the steam pressure.

The results from Table 5 show that for every $1 \mathrm{MW}$ rise in the steam turbine power the combined cycle power output increases by $0.91 \%$ at $24^{\circ} \mathrm{C}$ ambient temperature. For $30^{\circ} \mathrm{C}, 33^{\circ} \mathrm{C}, 35^{\circ} \mathrm{C}$ ambient temperatures, the combined cycle output show a progressive increase by $0.78 \%, 0.71 \%$ and $0.68 \%$ respectively. It further showed 
that beyond the steam pressure of $100 \mathrm{bar}$, there is a gradual decrease in the overall power output. Figure 5 revealed that at an ambient temperature of $24^{\circ} \mathrm{C}$ and Humidity of $70 \%$, the steam generated in the high pressure section of the HRSG increase progressively over the steam pressure range. This implies that a better performance is reached by the steam cycle.

Figures 6-8 present the effects of the site parameters on the total heat rate, steam turbine efficiency and

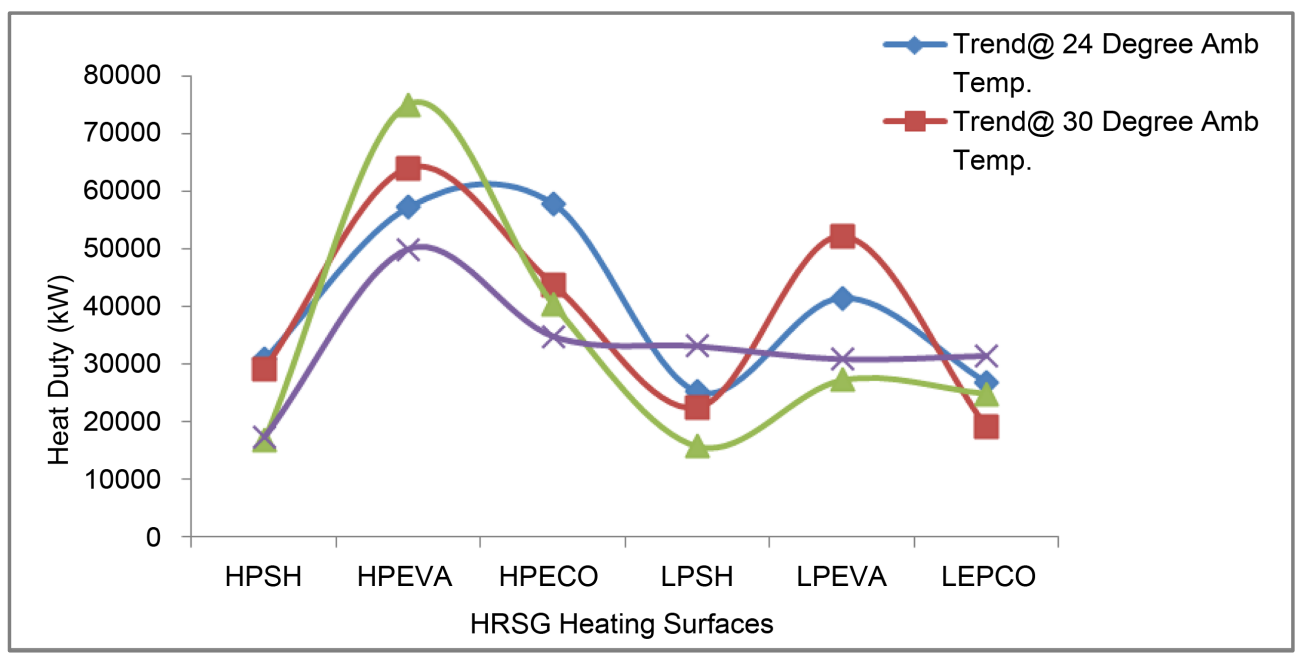

Figure 4. Effects of ambient temperature and humidity on HRSG heat duty performance [8].

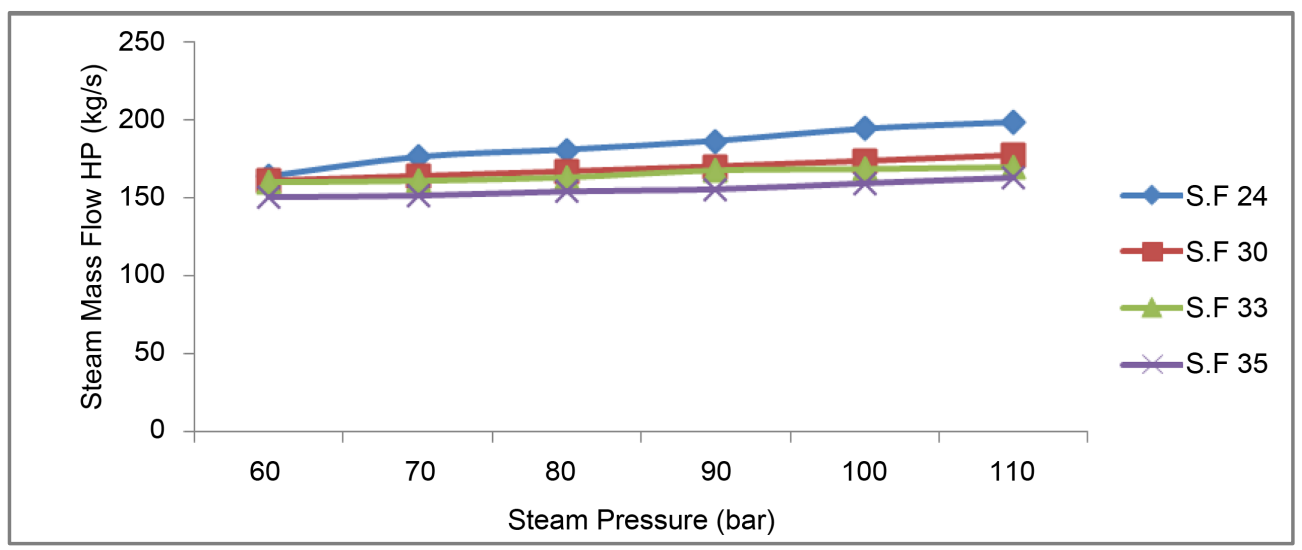

Figure 5. Effects of ambient temperature, humidity and steam pressure on steam generation.

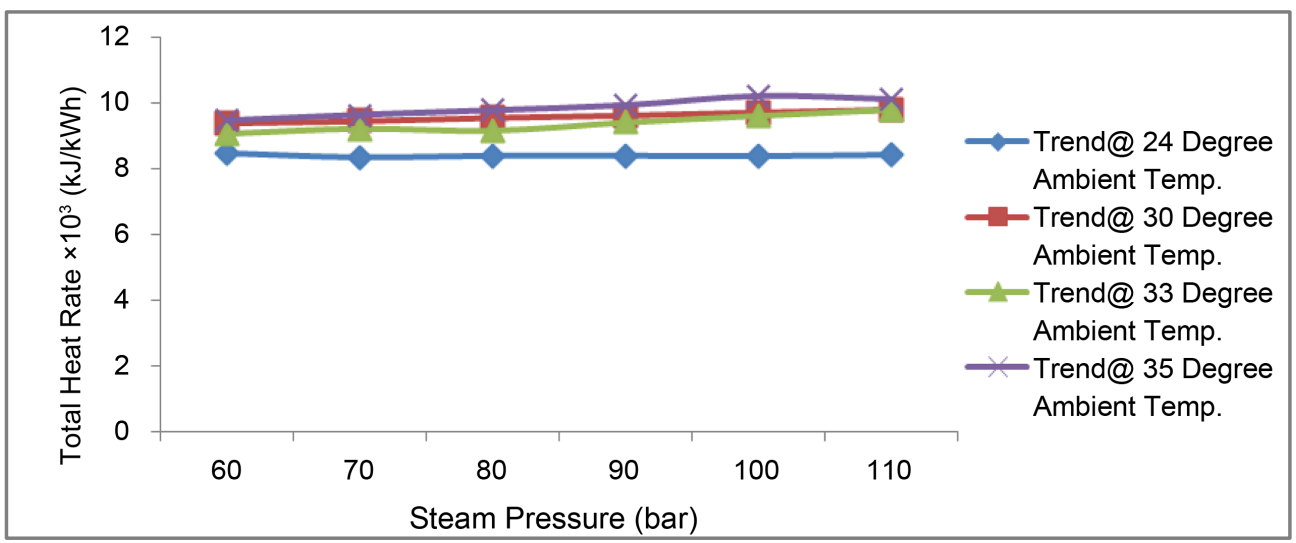

Figure 6. Effects of ambient temperature, humidity and steam pressure on total heat rate. 


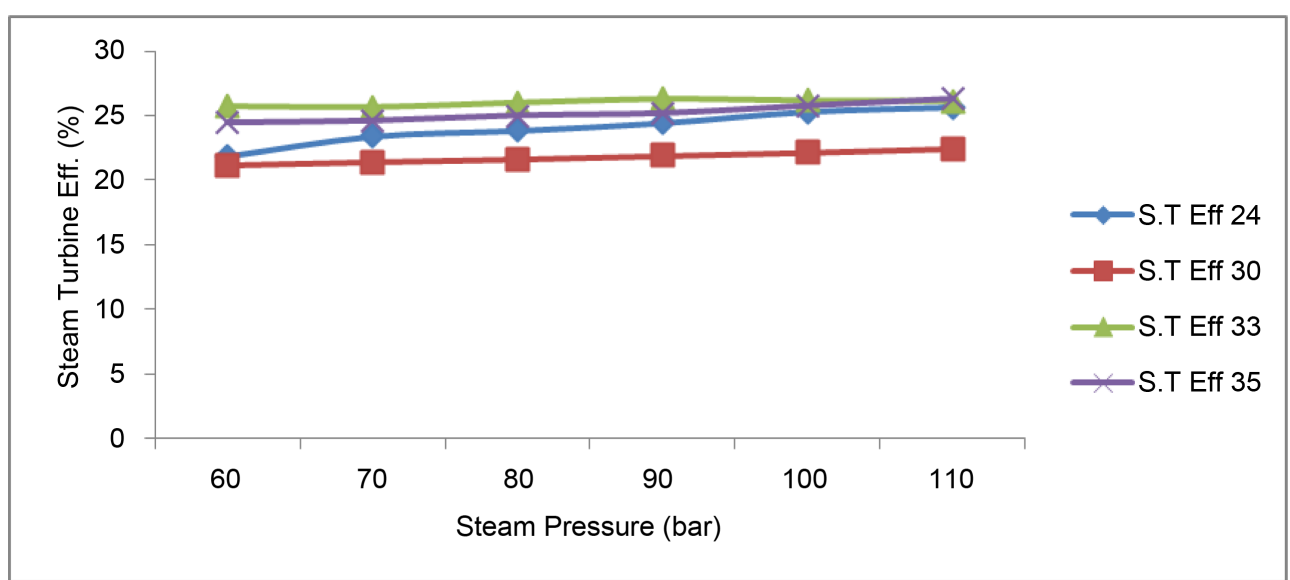

Figure 7. Effects of ambient temperature, humidity and steam pressure on steam turbine efficiency.

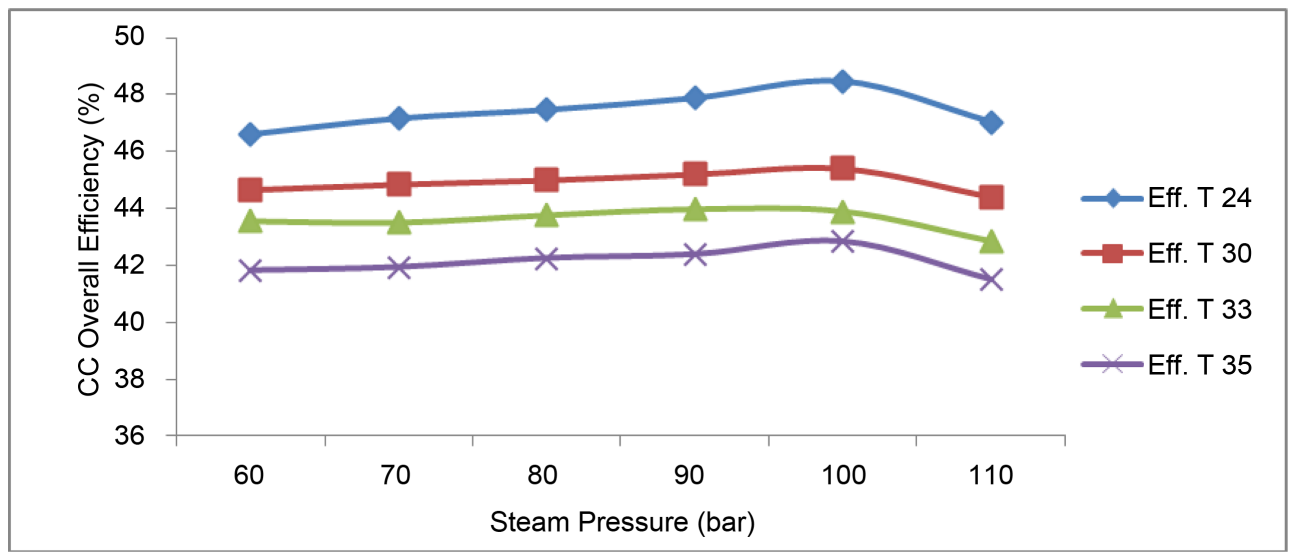

Figure 8. Effects of ambient temperature and steam pressure on combined cycle efficiency.

combined cycle efficiency at different steam pressure. Figure 6 further shows that the combined cycle total heat rate increases by about $0.004 \%$ at $24^{\circ} \mathrm{C}$ ambient temperature, $0.008 \%$ at $30^{\circ} \mathrm{C}$ ambient temperature, $0.014 \%$ at $33^{\circ} \mathrm{C}$ ambient temperature and $0.015 \%$ at $35^{\circ} \mathrm{C}$ for every 1 bar rise in the steam pressure under the various consideration. This means that as the ambient temperature increases, the plant overall heat rate also increases in diverse proportion. At $33^{\circ} \mathrm{C}$ ambient temperature, there was a sharp increase in the steam turbine efficiency as the steam pressure increase by $10 \mathrm{bar}$ as shown in Figure 7. Figure 8 revealed that at $24^{\circ} \mathrm{C}$ ambient temperature the combined cycle power output increase by $0.26 \%$ for every $1 \mathrm{~kg} / \mathrm{s}$ rise in the steam flow, while at $30^{\circ} \mathrm{C}$ ambient temperature, the combined cycle power output increase by $0.20 \%$ for every $1 \mathrm{~kg} / \mathrm{s}$ rise in steam flow. At $33^{\circ} \mathrm{C}$ and $35^{\circ} \mathrm{C}$ ambient temperatures, the combined cycle power output increases by $0.19 \%$ and $0.17 \%$ respectively for every $1 \mathrm{~kg} / \mathrm{s}$ rise in steam flow. Figure 9 and Figure 10 show that the combined cycle overall efficiency decreases progressively as the total heat rate of the system increases. This implies that at optimum performance of the HRSG, where effective heat exchange occurs and steam generation is improve, the cycle performance better. The overall results show that as the steam flow increases with increase in steam pressure at favourable ambient conditions, the combined cycle power output increase also. But further increase in the ambient temperature to an average of $31^{\circ} \mathrm{C}$ shows a fall in the plant overall power output. The results were validated with the works of [21] [22], which show the effects of heat recovery system on the overall performance of combined cycle power plant.

\section{Conclusion}

It may be pertinent to state here that though much of the data collected are obtained from the performance records of the GT13E2 Gas Turbine located within the tropical environment, the results of this investigation can be applied on similar power plant elsewhere. From the data analysis, it can be generally said that the climatic 


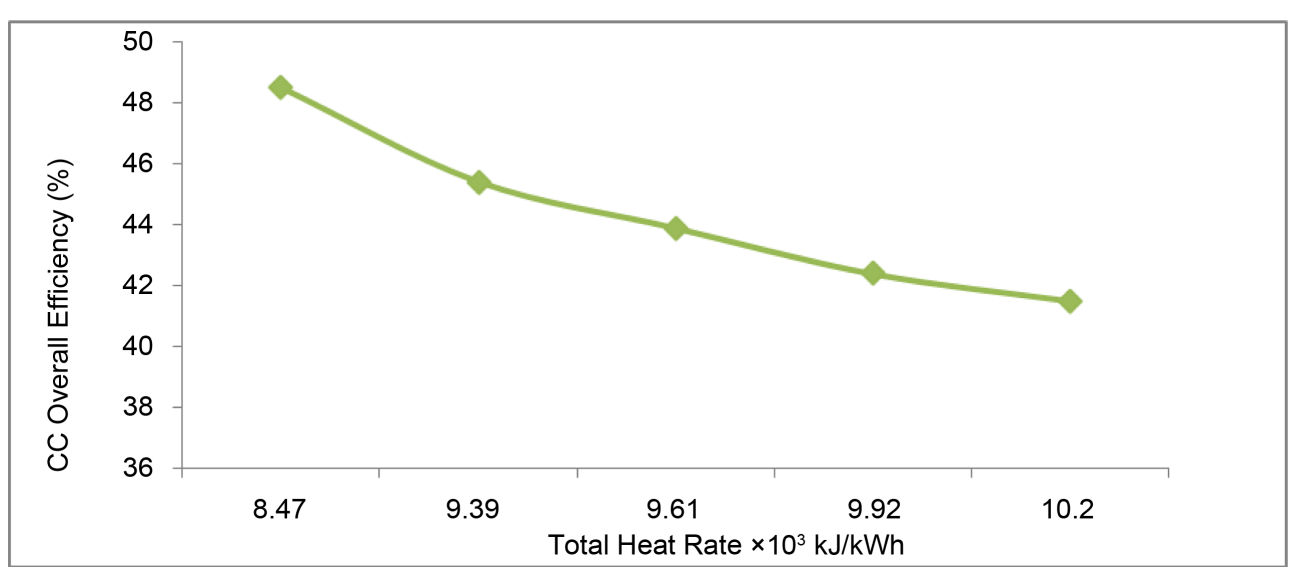

Figure 9. Effect of heat rate on combined cycle efficiency.

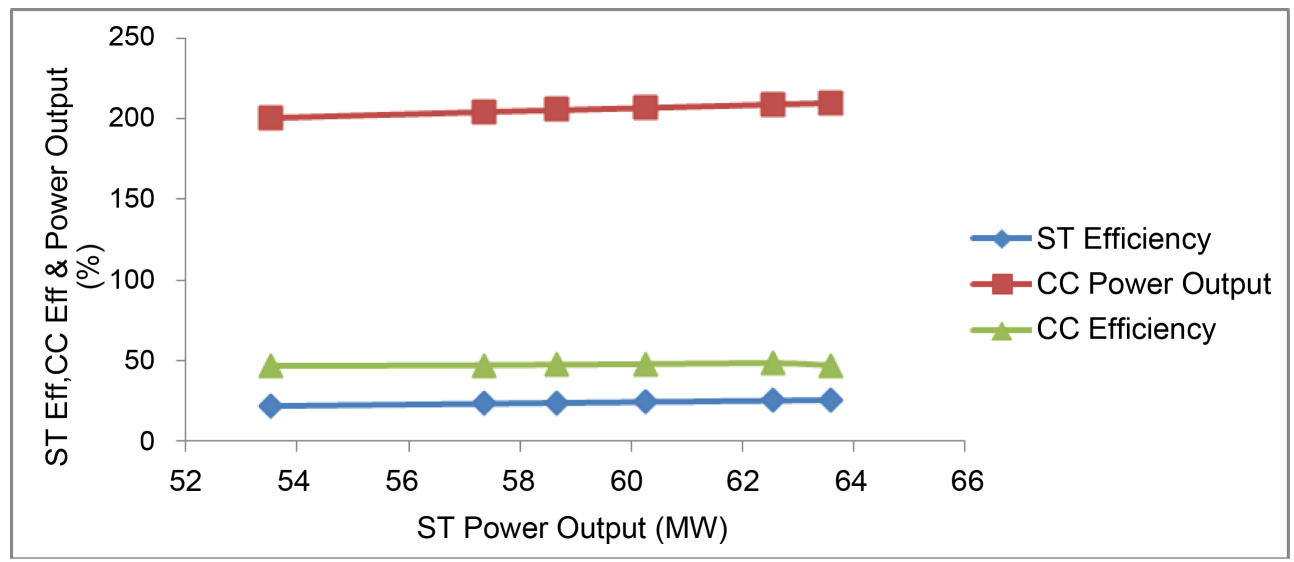

Figure 10. Effects site parameters and heat recovery characteristics on steam turbine efficiency, combined cycle power output and efficiency.

condition is peculiar to the tropical zone. This particular area of the study has a mean daily value of about $30^{\circ} \mathrm{C}$ which varies only slightly on both sides of this value as against the general design ambient temperature of $15^{\circ} \mathrm{C}$. The investigation reveals the percentage influence of the various gas turbine operating parameters and heat recovery property on the overall plant output. This assessment will actually aid concerned engineers, operators and product developers on understanding key parameters that influence the combined cycle performance with regard to geographical location. It provides technical and operational guide on the need to modified designs or augment the plant for optimum performance.

\section{References}

[1] Lebele-Alawa, B.T., Hart, H.T., Ogaji, S.O.T. and Probert, S.D. (2008) Rotor-Blades’ Profile Influence on a Gas Turbine's Compressor Effectiveness. Applied Energy, 85, 494-505. http://dx.doi.org/10.1016/j.apenergy.2007.12.001

[2] Lebele-Alawa, B.T. (2010) Axial Thrust Responses Due to a Gas Turbine's Rotor Blade Distortions. Journal of Engineering Physics and Thermo Physics, 83, 991-994. http://dx.doi.org/10.1007/s10891-010-0423-2

[3] Adumene, S., Le-ol, A.K. and Amadi, R.K.C. (2015) Modeling Compressor's Initial Operating Conditions Effect on Turbine Performance in the Tropical Rainforest. American Journal of Engineering Research, 4, 80-88.

[4] Capehart, B.L. (2007) Encyclopedia of Energy Engineering and Technology. Taylor and Francis Group, Boca Raton.

[5] Soares, C. (2008) Gas Turbines: A Handbook of Air, Land, and Sea Applications. Elsevier Science, Burlington.

[6] Heselton, K.E. (2005) Boiler Operator’s Handbook. Fairmont Press, Liburn Georgia.

[7] Higdon, C.R., Loules, B.M. and Lynn, S. (1990) “A Novel Heat-Recovery Process for Improving the Thermal Efficiency of Gas Turbines in Electric Power Generation. Proceedings of the American Power Conference, 52, 216. 
[8] Adumene, S. and Lebele-Alawa, B.T. (2015) Performance Optimization of Dual Pressure Heat Recovery Steam Generator in the Tropical Rainforest. Engineering, 7, 347-364. . http://dx.doi.org/10.4236/eng.2015.76031

[9] Cerri, G. and Sciubba, E. (1987) Aero-Derived Reheat Gas Turbines Steam Injection into the Afterburner. Advanced Energy Systems Division Publication AES, 3, 79-86.

[10] Felster, S., Favrat, D. and Von Spakovsky, M.R. (2001) The Thermo Economic Analysis and Environomic Modeling and Optimization of the Synthesis and Operation of Combined Cycle with Advanced Options. Engineering for Gas Turbine and Power, Transaction of ASME, 123, 717-726.

[11] Lebele-Alawa, B.T. and Le-ol, A.K. (2015) Improved Design of a 25MW Gas Turbine Plant Using Combined Cycle Application. Journal of Power and Energy Engineering, 3, 1-14. http://dx.doi.org/10.4236/jpee.2015.38001

[12] Tiwari, A.K., Hasan, M.M. and Islam, M. (2012) Effect of Operating Parameters on the Performance of Combined Cycle Power Plant. 1(7). http://doi:10.4172/scientificreports.351

[13] Kumar, P. (2010) Optimization of Gas Turbine Cycle Using Optimization Technique. M. Eng. Thesis, Department of Mechanical Engineering, Thapar University, India.

[14] Ahmed, S.Y. (2013) Performance of the Combined Gas Turbine-Steam Cycle for Power Generation. Mathematical Theory and Modeling, 3, 234-244.

[15] Yadav, J.P. and Singh, O. (2006) Thermodynamic Analysis of Air Cooled Simple Gas and Steam Combined Cycle Plant. Journal of Institution of Engineers (India)-Mechanical Engineering, 86, 222.

[16] Srinivas, T., Gupta, A.V.S. and Reddy, B.V. (2007) Generalized Thermodynamic Analysis of Steam Power Cycles with " $\mathrm{n}$ " Number of Feed Water Heaters. International Journal of Thermodynamics, 10, 177-185.

[17] Thamir, K.I. and Rahman, M.M. (2012) Effect of Compression Ratio on Performance of Combined Cycle Gas Turbine. International Journal of Energy Engineering, 2, 9-14.

[18] Nkoi, B. and Lebele-Alawa, B.T. (2015) Comparative Assessment of Combined-Heat-and-Power Performance of Small-Scale Aero-Derivative Gas Turbine Cycles. Journal of Power and Energy Engineering, 3, 20-32. http://dx.doi.org/10.4236/jpee.2015.39002

[19] Lebele-Alawa, B.T. and Asuo, J.M. (2011) Exergy Analysis of Kolo Creek Gas Turbine Plant. Canadian Journal of Mechanical Science and Engineering, 2, 172-184.

[20] Ebele-Alawa, B.T. and Jo-Appah, V. (2015) Thermodynamic Performance Analysis of a Gas Turbine in an Equatorial Rain Forest Environment. Journal of Power and Energy Engineering, 3, 11-23. http://dx.doi.org/10.4236/jpee.2015.31002

[21] Mohammad, T.M., Pouria, A., Abdolsaeid, G.K. and Mohammad, N.M.J. (2012) Exergic and Economic Evaluation of the Effect of HRSG Configurations on the Performance of Combined Cycle Power Plants. Journal of Energy Conversion and Management, 58, 47-58. http://dx.doi.org/10.1016/j.enconman.2011.12.020

[22] Vytla, V.V.S.K. (2005) Thesis on CFD Modeling of Heat Recovery Steam Generator and Its Components Using Fluent. College of Engineering, University of Kentucky, Lexington. 


\section{Nomenclature/Abbreviation}

$Q_{H P_{S H}}$

$Q_{H P_{E V}}$

$Q_{H P_{E C O}}$

$Q_{L P_{S H}}$

$Q_{L P_{E V}}$

$Q_{L P_{E C O}}$

UA

H P

L P

S T

G T

C C

LMTD

$H R_{T}$

$m_{\text {sHP }}$

$m_{s L P}$

MCR

HRSG

HMI
Heat Duty of the Superheater High Pressure Section

$\mathrm{kW}$

Heat Duty of the Evaporator in High Pressure Section

$\mathrm{kW}$

Heat Duty of the Economizer in High Pressure Section

$\mathrm{kW}$

Heat Duty of the Superheater Low Pressure Section

Heat Duty of the Evaporator in Low Pressure Section

$\mathrm{kW}$

$\mathrm{kW}$

$\mathrm{kW}$

Heat Duty of the Economizer in Low Pressure Section

Heat Transfer coefficient per unit Area

$\mathrm{kW} / \mathrm{K}$

High Pressure

Low Pressure

Steam Turbine

Gas Turbine

Combined Cycle

Log Mean Temperature Difference

Total Heat Rate

$\mathrm{kJ} / \mathrm{kWh}$

High Pressure Steam Generation

$\mathrm{kg} / \mathrm{s}$

$\mathrm{kg} / \mathrm{s}$

Low Pressure Steam Generation

$\mathrm{kg} / \mathrm{s}$

Maximum Steam Circulation Rate

Heat Recovery Steam Generator

Human Machine Interface 